\title{
REPLY
}

\section{RETIREMENT SECURITY AND TAX POLICIES: A REPLY}

\author{
Michael J. Graetz $\dagger$
}

\section{INTRODUCTION}

In an Article published in the April 1987 issue of the University of Pennsylvania Law Review, I urged that the three major components of this nation's retirement income system-Social Security, and income tax preferences for both employer-sponsored pension plans and individual retirement savings-be analyzed as a comprehensive national retirement income security program. ${ }^{1}$ I demonstrated that such an integrated view of this tripartite retirement security system reveals serious problems both with Social Security and with the generally applauded "tax expenditure" provisions for private pensions and individual savings. Viewing the three elements as a unified retirement security arrangement demonstrates that the core unfairness of this nation's retirement security program is the regressivity of its taxing structure and the incapacity of low- and moderate-wage earners to maintain post-retirement their prior standard of living. Significantly, this conclusion contradicts directly the contentions of many critics of social security who complain about its failure to replicate the payment and distribution structure of an "actuarially fair" insurance system.

In the May 1988 issue of this law review, Professor Nancy J. Altman criticized my analysis. " She complains that my "limited focus" is grounded "solely" in "the perspective of tax policy," asserts that I "would inadvertently weaken the long-run stability of Social Security by transforming it from a social insurance program to a welfare pro-

† Justus S. Hotchkiss Professor of Law, Yale Law School. B.B.A. 1966, Emory University; LL.B. 1969, University of Virginia.

1 See Graetz, The Troubled Marriage of Retirement Security and Tax Policies, 135 U. PA. L. REv. 851, 852-53 (1987) [hereinafter Troubled Marriage].

2 See Altman, The Reconciliation of Retirement Security and Tax Policies: A Response to Professor Graetz, 136 U. PA. L. Rev. 1419 (1988) [hereinafter Reconciliation].

${ }^{3}$ Id. at 1419, 1424. 
gram,"4 and presents her "defense" of tax expenditures for employersponsored pension plans. 5 . Ultimately, she embraces the status quo on the ground that the various components of our retirement income system "demonstrate an over-arching logic, despite the incremental and fragmented way in which the system has developed." $\mathrm{My}$ purpose here is to reply to Professor Altman's Article.

\section{Professor Altman Agrees with my Analysis}

Both the tone of Professor Altman's response, and her emphasis on disagreements with my specific policy suggestions, serve to conceal the extent to which Professor Altman agrees with both my fundamental premises and my general analysis of retirement income security policy. Indeed, the following recapitulation of her explicit endorsements of the essential elements of my analysis demonstrates that our disagreements lie not in our evaluations of the ills of the present system, but rather in the specific remedies we each would advance to cure them.

First, Professor Altman explicitly concurs in my statement of the appropriate goal of national retirement security policy, stating: "Professor Graetz appropriately defines the goal of national retirement income security policies as the replacement of pre-retirement wages at a level sufficient to maintain the standard of living of at least low-and perhaps even moderate-income workers." that tax burdens should be distributed in accordance with people's ability to pay. ${ }^{\circ}$

Second, Professor Altman endorses the analytical perspective of my Article, expressly accepting my view that the three major components of this nation's retirement security program-Social Security, tax-favored employer-sponsored private pensions, and individual savings-should be addressed as a "unitary whole."10 Although, as discussed below, she fails to fulfill this promise in her own analysis, Professor Altman relies on this unified approach in defending Social

1 Id. at 1427.

- See id. at 1439.

${ }^{6} I d$. at 1446.

7 This reply was not published in conjunction with Professor Altman's response because the editors of volume 136 of this law review provided no such opportunity. The editors of volume 137 regard this debate of sufficient import to warrant publication now.

${ }^{8}$ Reconciliation, supra note 2, at 1441 n.86 (citing Troubled Marriage, supra note 1 , at 855-56).

${ }^{9}$ See id. at 1435 .

10 Id. at 1419-20, 1423. 
Security from its critics on the right:

[A] criticism of the retirement income system on the basis of the rate of return provided by Social Security to higher income workers would be unwarranted in light of the large tax subsidies for private pensions that disproportionately benefit those same workers claimed to be unfairly treated by social security. ${ }^{11}$

Indeed, Professor Altman details the "compartmentalized, fragmented manner" in which retirement income security arrangements and policies have evolved. ${ }^{12}$ She emphasizes that "Congress has traditionally considered Social Security and private pension legislation in separate legislative vehicles, generally in different years, and usually without reference to the impact of the changes on other parts of the retirement income system."13 Professor Altman also points out that the subcommittee arrangements and assignments of the House Ways and Means and Senate Finance Committees are not well suited to produce coherent retirement income policy. ${ }^{14}$ Despite her criticisms, however, she views such a process as producing a set of laws that, mirabile dictu, demonstrates an "overarching logic."15

Nevertheless, Professor Altman describes as "important" my "concern about the regressivity of the payroll tax with respect to the highest-income taxpayers,"16 regards me as "properly concerned about the burden that the payroll tax imposes on the working poor," with me that "reliance on voluntary private pensions as part of our national retirement income system is problematic," and characterizes as "sound" my criticisms of the private pension system. ${ }^{18}$ Finally, Professor Altman asserts that I "properly" denounce the "current distribution of retirement income" and agrees that change is needed. ${ }^{19}$

In sum, Professor Altman concurs in my statements of the appropriate goals of both retirement security and tax policies, accepts my arguments that-contrary to the usual practice of both Congress and other critics-the tripartite system for providing retirement income should be analyzed as a comprehensive whole, concedes the merits of

11 Id. at 1424 n.21 (citing Troubled Marriage, supra note 1, at 852, 871-72).

12 See id. at 1421-22.

13 See id at 1421-22.

I4 See id. at 1422 n.14.

$15 \mathrm{Id}$. at 1446.

${ }^{16} \mathrm{Id}$. at 1437.

$17 \mathrm{Id}$. at 1435.

18 See id. at 1439.

19 See id. at 1443. 
my criticisms of distributions of both tax burdens and retirement income under the present system, and even grants the soundness of my ultimate concerns about the wisdom of our heavy reliance on voluntary private pensions to fulfill national retirement income security policies. Professor Altman's complaints therefore are not directed at the fundamental analysis of my Article; rather, they are aimed at the specific reforms that I advanced.

\section{Professor Altman's Policy Arguments are not Convincing}

Battles within the same church are often the most contentious. In responding to my Article, Professor Altman has argued for the replacement of some of my specific suggestions for reform with proposals of her own. Unfortunately, Professor Altman has masked her essential agreement with my analysis by rhetorically overstating her criticisms, by exaggerating her generally unsupported claims that my specific proposals would not only produce consequences precisely opposite to those I both intend and expect, but also would undermine-perhaps even destroy-both the Social Security and private pension systems, and by burying many explicit accordances with my analysis in her footnotes. Perhaps the marketing of journal articles requires such excesses.

In an effort to avoid similar hyperbole here, I shall not discuss at length the policy differences that divide Professor Altman and me. In general, she would eschew the direct changes I recommend in the Social Security tax structure and instead would redress the inequities at both the bottom and top ends of the Social Security tax structure through adjustments in the income tax. ${ }^{20}$ In addition, she would address the problems of private pensions by strengthening the regulatory requirements for voluntary private pensions, rather than by either imposing a tax on the income of pension funds to finance increased retirement income for low- and middle-income taxpayers, or by mandating employer provision of some minimum level of pensions for their employees. ${ }^{21}$ Professor Altman does not discuss the issues I raised with respect to income tax incentives for individual savings for retirement. ${ }^{22}$

In my Article, I stated that the substantial social security tax burden on the working poor might be alleviated by exempting low income workers from social security tax after they satisfied a new minimum social security benefit eligibility requirement by paying taxes for some

20 See id. at $1435-39$.

21 See id. at 1439-45.

${ }^{22}$ See Troubled Marriage, supra note 1, at 894-906. 
minimal number of quarters, ${ }^{23}$ or even by adding an exemption level to the payroll tax. ${ }^{24}$ Professor Altman recommends strengthening the Earned Income Tax Credit ("EITC") provisions of the income tax, a course I considered but rejected. ${ }^{25}$ Professor Altman urges a variety of structural advantages for the EITG, but makes her case for relying on the EITC on the ground that an exemption, or even a minimum payment requirement, for the payroll tax would undermine the social security system. ${ }^{28}$ Of course, I have neither desire nor intention to undermine Social Security, nor do I regard my proposals as likely to do so. Professor Altman and I simply differ in our judgments both about the efficacy of the EITC and about what kinds of changes would threaten the political stability of social security. ${ }^{27}$ Moreover, the fact that the EITC has not, thus far, become embroiled in the politics of welfare may be as much attributable to its limited scope, usage, and coverage as to its location in the Internal Revenue Code. Expansions of the EITC of the sorts urged by Professor Altman might well result in subjecting that provision to attack by the very same anti-welfare political forces that she perceives as so threatening to the social security system. ${ }^{28}$

23 See id at 864-68.

24 See id. at 906.

${ }^{25}$ Compare Reconciliation, supra note 2, at 1435-36 with Troubled Marriage, supra note 1 , at 866-68.

${ }^{28}$ See Reconciliation, supra note 2, at 1433-34, 1437.

27 Professor Altman regards political stability as the critical normative standard in her evaluation of social security. See Reconciliation, supra note 2, at 1424-27, 1446. She does not, however, offer a systematic analysis to defend her statements concerning what changes threaten or enhance political stability of specific aspects of social security. Indeed, she only offers overblown rhetoric about how my proposals would "introduce elements of welfare into the design of Social Security." Id. at 1432 \& n.49. It hardly needs saying that the relationship of insurance and welfare elements of the social security system have long been debated, or that Professor Altman's firm characterizations of what would transform an "insurance" program into a "welfare" program are controversial. See, e.g., Cover, Social Security and Constitutional Entitlement, in Social SeCURITY: BEYOND THE Rhetoric OF CRISIS 69-87 (T. Marmor \& J. Mashaw eds. 1988) [hereinafter Social Security]; Thompson, The Social Security Reform Debate, 21 J. Econ. Literature 1425, 1436-38 (1983). Professor Altman herself acknowledges that no private insurance program "contains the kind of benefit formula found in Social Security." Reconciliation, supra note 2, at 1432.

Professor Altman does not discuss any political problems with implementing her recommendations through the income tax and, in fact, one often gets the sense that she is comparing a potentially ideal income tax with a politically constrained social security system. She, for example, perceives no political problems with making the federal income tax more progressive, or in expanding its base to include additional social security benefits. See id. at 1438. This confidence seems ironic, coupled, as it is, with footnote references to the Tax Reform Act of 1986. For discussion of the Tax Reform Act of 1986 as signalling the demise of progressivity as the guiding principle for fairness in the distribution of federal tax burdens, see Graetz, The Truth About Tax Reform, 40 U. Fla. L. Rev. 617 (1988).

${ }^{28}$ I also suggested that experience with other tax credit provisions implies that the 
With respect to the problems of regressivity of the social security tax that occur because of the ceiling on wages subject to the wage tax, Professor Altman and I also vary in our judgments. There has long been a mistaken view that it is the social security system standing alone, rather than the entire tripartite retirement program, that should be evaluated. This erroneous conception has entrenched the view that elimination of the payroll tax wage ceiling requires a proportional increase in social security benefits. ${ }^{29}$ Notwithstanding Professor Altman's concurrence that the entire three-part retirement security system should be viewed as a unified whole ${ }^{30}$ and her explicit use of private pension benefits elsewhere in evaluating the distributional fairness of retirement income, ${ }^{31}$ in evaluating my proposals here, she makes the classic error of treating social security benefits as if they were the sole source of workers' retirement income..$^{32} \mathrm{My}$ fundamental point that our national retirement insurance program must be analyzed as including tax-favored private pensions and individual savings, in addition to Social Security, is simply ignored in her analysis of the wage ceiling. That Professor Altman makes this particular mistake is especially disappointing because her other work makes it clear that she is acutely aware that the distribution of retirement income from private pensions is skewed heavily in favor of higher-earning workers. ${ }^{33}$

The debates between Professor Altman and me over appropriate changes in the private pension system seem to stem from differing empirical assessments rather than divergent analyses. We concur in our perceptions that changes are necessary, particularly to improve retirement income benefits for low- and moderate-income workers. ${ }^{34} \mathrm{I}$ suggest that it may be necessary to mandate private pensions with broader coverage and a different distribution of retirement income or, alterna-

EITC may not be claimed by a large number of people entitled to it. See Troubled Marriage, supra note 1, at 866-67. The potential EITC error rate renders problematical reliance on such a provision as the mechanism for providing payroll tax relief for the working poor. Indeed, the earned income tax credit accounted for nearly $25 \%$ of all error notices issued to taxpayers for 1987 tax returns. EITC-related errors included taxpayers claiming the credit when they were not entitled to it, taxpayers failing to claim the credit when they were entitled to it, and taxpayers claiming an incorrect amount for the credit. See San Francisco Newsletter Cites Refund Delays Caused by Social Security Number and Earned Income Credit Calculation Foul-Ups, 12 TAX Analysts' Daily Tax Highlights \& Documents 2243 (1989).

${ }_{29}$ See Troubled Marriage, supra note 1 , at 870-72.

so See supra note 10 and accompanying text.

31 See Reconciliation, supra note 2, at 1424 n.21.

32 See id. at 1432-34.

s3 See Altman, Rethinking Retirement Income Policies: Nondiscrimination, Integration, and the Quest for Worker Security, 42 TAx L. REv. 433, 435-36 (1987) [hereinafter Altman, The Quest].

${ }^{34}$ See Reconciliation, supra note 2, at 1443. 
tively, to impose a tax on pension funds or pension assets to finance additional benefits and payroll tax reductions for low and moderateincome workers. ${ }^{35}$ Professor Altman, on the other hand, urges additional requirements for coverage, vesting, and integration with Social Security for voluntary employer pension plans, coupled with changes to make the income tax more progressive. ${ }^{36}$ Ultimately, which of these is the wiser course turns on empirical judgments concerning their likely consequences. As Professor Altman well recognizes, the history of imposing regulatory requirements on voluntary employer-sponsored pension plans is not encouraging if the primary goal is to provide retirement income to allow low and middle-income workers to maintain their standard of living post-retirement. ${ }^{37}$ Nevertheless, she regards the appropriate path as further incremental changes in the existing system. I have become convinced that more drastic measures are warranted.

\section{ConCLUSION}

In my earlier Article, I evaluated how the Social Security system, tax-favored employer-sponsored private pensions, and income tax incentives for individual retirement savings mesh to form a comprehensive national retirement income security program. I also appraised the financing of this tripartite retirement security system from a tax policy perspective. My analysis revealed many deficiencies in the distribution of both tax burdens and retirement income benefits. I found the redistributive aspects of Social Security benefits to be largely offset by the advantages provided to high-income families through the tax treatment of employer-sponsored private pensions and tax incentives for individual retirement savings. I also found the regressive financing of social security to be unjustified. Some might say that I found the existing system to be "incoherent and possibly perverse."38

In this reply, I have endeavored principally to set the record straight. Nothing in Professor Altman's response casts doubt on the es-

${ }^{36}$ See Troubled Marriage, supra note 1, at 906-08. I purposely suggest a tax rate significantly lower than the lowest personal income tax rate to avoid the prospect suggested by Professor Altman that deferred compensation would be disadvantaged in comparison with current compensation. Compare id. at 908 (suggesting a rate of 10\%) with Reconciliation, supra note 2 , at 1443 n.96.

${ }^{38}$ See Reconciliation, supra note 2 , at 1444 n.99, 1445-46.

${ }^{37}$ See $i d$. at 1446 ("[T]he private pension component falls far short of the equity, adequacy, and security essential to a national retirement income system."); Troubled Marriage, supra note 1, at 874-94. See generally Altman, The Quest, supra note 33, at $456-500$ (critiquing nondiscrimination rules).

${ }^{38}$ Indeed this is exactly what some have said. See Introduction to Social SecurITY, supra note 27 , at 11 . 
sential analysis of my Article. Indeed she concurs explicitly with my major analytical points. Our disagreements over methods of implementation are real, but seem largely to turn on differences in judgment about how our mutual goals might best be fulfilled. 